\title{
The Role of Pesantren in Improving the Religiosity of Tahfidz Al-Quran Santri in Yogyakarta
}

\author{
Nurul Aisyah ${ }^{1, *}$ Lailia Farhatus Sofiah ${ }^{2}$ \\ ${ }^{1}$ Dept. Islamic Education Universitas Muhammadiyah Yogyakarta, Indonesia \\ ${ }^{2}$ Dept. Islamic Education Universitas Muhammadiyah Yogyakarta, Indonesia \\ *Email: nurulaisyah@umy.ac.id
}

\begin{abstract}
Pesantren in Indonesia has played a role in forming the nation's children's religiosity. Besides, each pesantren has a different style in the efforts to establish religiosity. This study aims to compare each pesantren's role in improving the religiosity of the santri of the Tahfidz Al-Quran in the Yogyakarta Region and the differences in the methods used by the two institutions. This type of research is field research with a qualitative case study research design. Data collection techniques were participatory interviews, participant observation, and documentation. Data credibility techniques were through source triangulation and technique triangulation. The data analysis technique was by the Creswell qualitative data analysis technique. The results found in the pesantren of Al-Munawwir Nurussalam and Nurul Ummahat have roles in various ways, namely a) increasing hablumminallah (creed, worship, and knowledge) santri of tahfidz Al-Quran, b) increasing hablumminannas, and c) increasing hablumminal'alam. The methods used to improve the Religiosity of the students of the Al-Quran are a) advice from the Kyai, b) study of classical Islamic books, c) habituation, d) modeling, e) reward, and f) punishment. This study's results can provide significant benefits in the efforts to establish the religious Religiosity for santri in other pesantren in Indonesia and overseas.
\end{abstract}

Keywords: Role of Pesantren, Santri of Tahfidz Al-Quran, Religious Religiosity

\section{INTRODUCTION}

The santri tahfidz. Al-Qur'an has a good reputation among the Indonesian Muslim community. The importance of pesantren is not only in terms of the number of students relative to the general student but also in terms of the pesantren's strategic position in directing the direction of Islam in the country [1][2]. The Indonesian Islamic community believes that the tahfidz Al-Qur'an santri have a higher level of Religiosity and degree than ordinary santri. It is because santri tahfidz AlQur'an study religion and memorize Al-Qur'an simultaneously.

The Indonesian Muslim community believes that reading and memorizing the Al-Quran is a noble practice and can bring blessings [3]. Therefore, it is not surprising that the Indonesian Muslim community honors a hafiz AlQur'an. People believe that if we glorify a hafiz AlQur'an, we can get blessings from their Al-Qur'an memorization. The community assumes that pesantren is one of the educational platforms that can increase children's Religiosity. One of them is due to the increasing development of pesantren culture through the formation of identity and the integration of the essential and instrumental values of pesantren [4], as the principal capital of pesantren in developing its role.

Pesantren is an institution that has been established to educate the nation from the period of struggle against colonialism and is currently a center of study and is very useful in fostering student character [5][6][7][8]

This research will further examine how the pesantren's role and the different methods used by the pesantren in increasing the Religiosity of the tahfiz Al-Quran students.

\section{LITERATURE REVIEW}

\subsection{Pesantren}

Pesantren cannot be equated with public school educational institutions because pesantren combines three 
elements of education, namely (a) worship to instill faith, (b) tabligh for science, and (c) charity to realize community activities in everyday life [9]. Fitriah et al. argued that pesantren as educational institutions not only play a role in the development of Islamic education but also play a role in the progress of the development of the surrounding environment [10][11][12]. Pesantren plays a role in building the surrounding environment, which is manifested through several social activities. For example, social service activities, community service, counseling, majlis taklim, or religious studies that may not be well understood by the community.

\subsection{The Purpose of The Pesantren}

Pesantren is to guide students to become human beings with Islamic personalities and become Islamic Preachers [13]. Then, pesantren are institutions that prepare santri to become experts in worship and religious knowledge. Besides, after graduating, students are expected to practice it in the surrounding community [13].

The elements of the pesantren are kyai, santri, pondok, mosque, and classical Islamic books [14] [15] [16]. There are various learning methods applied in pesantren, which vary from one pesantren to another. Some of them are sorogan, bandongan, and halaqah.

As one of the oldest educational institutions in Indonesia, Pesantren became the center of education in Indonesia. Pesantren has always been one of the main references in formulating the national curriculum (Asmani, 2016). Two reasons pesantren become the center of education in Indonesia. Firstly, pesantren is an educational institution that survives until now. The pesantren founded by Sunan Ampel in the 15th century was still a hermitage and has even survived.

Secondly, pesantren always develops according to existing conditions and situations. Islamic boarding schools before the Dutch colonial era only taught religious knowledge. However, after the Dutch entered and issued a new policy (related to educational institutions in Indonesia) in the 18th century, pesantren began to teach general science. The Dutch policy that only provided quality education to the Dutch themselves and their supporters made pesantren leaders look for ways to solve this problem. In 1934, KH A Wahid Hasyim initiated establishing a madrasah, where the general material taught in madrasas was $70 \%$, and the idea was approved by KH M Hasyim Asy'ari (Asmani, 2016: 6468). These reasons are more than sufficient to make pesantren Pesantren not only have a role in spreading Islam but also have a role in other areas of life. For example, in the economic, social, government / political fields, moral education in the era of globalization, character building, and the role in increasing students religiosity.

Each pesantren has its efforts to increase the religiosity of its students.

The researcher will further examine the role of pesantren in increasing Al-Qur'an tahfidz students' religiosity in the Yogyakarta region. Besides, the researcher will further examine the pesantren's methods to increase the religiosity of the students of the Al-Quran tahfidz.

\subsection{Religiosity}

A Muslim who follows the Al Quran and al-Hadith's daily activities in his life is commonly called religiosity [17]. Religiosity comes from the word religion (in English), religie (in Dutch), religio (in Latin), and addien (in Arabic), which means faith. Meanwhile, it also has defined a form of internalization of religious values, where norms are used to help human behavior both in human relations with God (hablumminallah), human relations (hablumminannas), and human relations with nature (hablumminal'alam) [18] [19].

Also, Shihab argues that the impact of Religiosity in social life can positively impact society's welfare, namely being able to increase the productivity of their performance and professionalism in the workplace [20]. Moreover, Religiosity is a condition due to one's behavior that stems from responses in his faith toward God's orders to achieve a good life now and hereafter [17].

The dimensions of Religiosity is religious awareness (belief in God) and diverse experiences [21] [22] [23]. On the other hand, Religiosity is a state of human dependence on God. The higher one's religiosity signifies a higher positive religious coping.

"Positive Religious Coping records "a sense of connection with a transcendent force, a secure relationship with a caring God, and a belief that life has a greater benevolent meaning," and this form of coping should promote distress reduction effects" [24].

This form of dealing with stress is in the way of reducing stress in worldly human problems automatically. Peace of life will be achieved.

\subsection{Santri of Tahfidz Al Quran}

The word "Al-Qur'an" comes from the word "qara'a" which means "to collect" [25]. The Qur'an is the word of Allah, which is a miracle that was revealed to the Prophet Muhammad through the Malaikat Jibril, which is written in the Mushaf, which is narrated in mutual concern and has worship value when reading it [26] 
Based on the description above, it can be concluded that what is referred to as santri tahfidz Al-Qur'an is someone who studies religion (where the learning resources used come from Arabic books), who lives near teachers/kyai (pesantren), and memorizes Al -Qur'an.

\section{METHODOLOGY}

This research uses a qualitative case study type. This study's research locations were Al-Munawwir Nurussalam and Putri Nurul Ummahat Pesantren.

The research subjects include pesantren caregivers, pesantren heads, and Al-Quran tahfidz students. The technique of taking the research subject used is purposive sampling, where the researcher takes the subject who understands the field to be studied. Researchers also use snowball sampling techniques, so researchers take research subjects who can provide data that has not been provided by the main research subject.

The data techniques used were semi-structured interviews, participatory observation, and documentation. Semi-structured interviews were conducted to see the background of the pesantren, the pesantren's role, and the methods used in increasing the Religiosity of the students of the Al-Quran tahfiz. Observation of passive participation is carried out to see the conditions in the pesantren, students' behavior in the tahfiz Al-Quran, and the process of increasing the students' religiosity tahfiz Al-Quran. Documentation is carried out to gather related supporting information, such as photos and documents.

In this study, the dimensions of religiosity used as indicators are the ideological dimension, the ritualistic dimension, and the knowledge dimension. These three dimensions are applied in the context of hablumminallah, hablumminannas, and hablumminal'alam.

The credibility of the data used is the source and technique triangulation. There are two ways: comparing the data from different persons and different techniques like the interview, observation, and documentation techniques until the data saturation is reached.

The data analysis technique used is from Creswell. The data analysis steps used were: 1) Providing raw data from interviews, observations, and documentation; 2) Reduce data and classify data according to themes (coding); 3) Describe the research data from the classification results; 4) Linking between pieces of data groups, and 5) Concluding.

\section{RESULT AND DISCUSSION}

The Pesantren of Munawwir Nurussalam and Nurul Ummahat have learned methods for increasing the level of Religiosity of santri.
Table 1. Methods for increasing the Religiosity of Santri

\begin{tabular}{|c|c|c|}
\hline \multirow[t]{2}{*}{ Religiosity } & \multicolumn{2}{|l|}{ Methods } \\
\hline & $\begin{array}{l}\text { Munawwir } \\
\text { Nurussalam }\end{array}$ & $\begin{array}{l}\text { Nurul } \\
\text { Ummahat }\end{array}$ \\
\hline \multirow[t]{2}{*}{ Habluminallah } & \multicolumn{2}{|l|}{ Kyai Advice } \\
\hline & \multicolumn{2}{|c|}{ Study Kitab Islam Klasik } \\
\hline \multirow[t]{2}{*}{ Habluminannas } & \multicolumn{2}{|l|}{ Modelling } \\
\hline & \multicolumn{2}{|l|}{ Habituation } \\
\hline Habluminalalam & \multicolumn{2}{|c|}{ Reward and Punishment } \\
\hline
\end{tabular}

\subsection{Kyai as a role model in pesantren}

The head of the pesantren stated that the role of the kyai is at the core of learning in the pesantren. For example, every speech and attitude that exists in a kyai becomes a striking thing that is paid attention to and obeyed by the students and all members of the pesantren. Kyai is a teacher who is able to have a big influence on the development of student learning through his advice and ends with his religious experience. This is in line with what Widigdo conveyed that a critical element of the experience of religiosity feels, which is an existential experience that occurs in the realm of feelings where the subject and object of experience are unity [27].

At the Nurul Ummahat Islamic Boarding School and the Nurrussalam N Saran Kyai Islamic Boarding School, it is an important factor in rebuilding the religiosity of the students. Based on the observation that Kyai is a role model in the pesantren who is able to support the worship of students, namely advice as to the intermediary. In this case, the santri will do what the kyai instructs because as a core figure in the Islamic education institution, the kyai is also obliged to transform Islamic knowledge to students both formally and informally so that the figures of kyai, caregivers, and ustadz are signficant in providing life examples [28]. Santri acknowledged that the orders from the kyai were absolute and must be carried out. Both the clerics of the Nurussalam and Nurul Ummahat Islamic Boarding Schools always provide advice so that students must always be active in congregational prayer, istiqomah in reciting and reading books, and not getting bored of the recitation in the pesantren. In addition, the kyai also advised on the virtues of congregational prayer, the virtues of reading the Koran, the virtues of fasting, almsgiving and others. 


\subsection{Learning Islamic books can help students to increase their religiosity study of Islamic books can help the santri to improve the Religiosity}

Pesantren residents, as community protectors, have a social and religious responsibility. In other words, pesantren becomes a place of reference for problems faced by society, especially in religious matters [28]. Therefore, this book of figh studies needs to be taught to students in order to support increased religiousness before plunging into the wider community or useful for itself

Learning Islamic books such as figh helps students gain knowledge about fardhu worship (prayer, fasting, zakat, hajj), 'ubudiyah (worship which concerns the context of hablumminallah) and muamalah (worship which concerns the context of hablumminannas) for example, the books of Taqrib, Fathul Qarib and Nihayatuz Zain. The study of the tafsir and hadith books adds to the santri's reference to hadiths related to worship. For example, they are taught the virtue of congregational prayer, the virtue of sunnah prayer, the virtue of sunnah fasting, the virtue of dhikr, the virtue of almsgiving. Besides, they also learn well-known reference books, such as Tafsir Jalalin, Tafsir al-Maraghi and Riyadus Shalihin. The differences in studying kitab Islam Klasik of both pesantren are as follows.

Table 2. Type of Kitab in Nurul Ummahat

\begin{tabular}{|l|ll|}
\hline Learning Methods & Boks \\
\hline Bandongan & $\bullet$ & Tafsir al-Maraghi \\
\hline Taqrar & $\bullet$ & Taqrib \\
& $\bullet$ & Akhlaqul Banat \\
& $\bullet$ & Shabibul Iman \\
\hline
\end{tabular}

Table 3. Type of Kitab in Nurussalam

\begin{tabular}{|c|c|}
\hline Learning Methods & Books \\
\hline Morning Bandongan & $\begin{array}{ll}\text { - } & \text { Riyadus Shalihin } \\
\text { - } & \text { Tafsir Jalalain } \\
\end{array}$ \\
\hline Night Bandongan & $\begin{array}{ll}\text { - } & \text { Nihayatuz Zain } \\
\text { - } & \text { Mambaus } \\
\text { - Sa'adah } \\
\text { - Khulasoh } \\
\text { - al-Hikam } \\
\text { - Ta'lim } \\
\text { - } & \text { Muta'alim. }\end{array}$ \\
\hline Sorogan & $\begin{array}{ll}\text { - } & \text { Safinatun Najah } \\
\text { - } & \text { Taqrib } \\
\text { - } & \text { Fathul Qarib } \\
\text { - } & \text { Fathul Mu'in } \\
\end{array}$ \\
\hline $\begin{array}{l}\text { Madrasah Diniyah (Grade } \\
\text { 1) }\end{array}$ & $\begin{array}{ll}\text { - } & \text { Mabadi'ul Fiqih } \\
\text { - } & \text { Aqidatul Awam } \\
\text { - } & \text { Akhlaqulil Banat } \\
\end{array}$ \\
\hline
\end{tabular}

\begin{tabular}{|l|ll|}
\hline & $\bullet$ & Sharaf Krapyak \\
& $\bullet$ & Nahwu Wadhih 1. \\
\hline Madrasah Diniyah (Grade & $\bullet$ & Aqidatul Islamiyah \\
& $\bullet$ & Nahwu Wadhih 2 \\
& $\bullet$ & Sharaf Krapyak \\
& $\bullet$ & Fathul Qarib \\
& Hidayatus Sibyan \\
\hline Madrasah Diniyah (Grade & $\bullet$ & Sharaf Krapyak \\
$3)$ & $\bullet$ & Qawa'idul Fiqih \\
& $\bullet$ & Jurumiyah \\
& $\bullet$ & Jawahirul \\
& & Kalamiyah \\
& $\bullet$ & Fathul Qarib \\
& $\bullet$ & Ta'lim Muta'alim. \\
\hline Madrasah Diniyah (Grade & $\bullet$ & Tafsir Ahkam \\
4) & $\bullet$ & Ushul Fiqih \\
& $\bullet$ & Qawa'idul Fiqih \\
& $\bullet$ & Tadzhib \\
& $\bullet$ & Musthalahal Hadits \\
& $\bullet$ & Ulumul Quran \\
\hline
\end{tabular}

4.3. Habituation and modeling are to stimulate santri to carry out muamalah worship activities regularly and in an orderly manner.

Worship activities such as prayer in congregation at Fajr, Maghrib and Isha '; dhikr after prayer; reading passages from Al-Quran such as Qs Al-Waqiah, Qs AlMulk and juz Amma; recital; Koran deposits; and Maqbarah. Both of these methods can increase the religiosity of students in habluminallah, habluminannas and hablumminal'alam.

The post-transformation process describes a change in a more religious mindset and more polite and beneficial behavior for the surroundings [29].

\subsection{Reward and punishment as a consequence in the learning process}

The technical implementation of the punishment method at the Nurussalam Pesantren is differentiated based on its activity program. Each activity program at the Nurussalam Pesantren has a different punishment system and is regulated by each management division. For example, punishments for worship programs are regulated by the worship division, and educational programs are regulated by the education division [30]. Then, punishments for worship programs are given on the 1 st week of each month, and punishment for the education programs is given on the 3rd week of each month [31].

Meanwhile, the technical implementation of the punishment method at the Nurul Ummahat Pesantren was made into one for all activity programs, both worship and education programs, and was regulated by the security 
and hygiene division. Then, the punishment is given every week, precisely on Friday morning.

Third, the technical implementation of the reward method at the Nurrussalam is differentiated based on the activity program. This means that each activity program has a different reward system and is regulated by each management division. For example, rewards for worship programs are regulated by the worship division, the education division regulates rewards for educational programs, and the hygiene division regulates rewards for hygiene programs [32]. Meanwhile, the technical implementation of the reward method at Nurul Ummahat is integrated into all activity programs. Both reward and punishment have a significant influence on students' religiosity, as supported by Steel [33]

\section{CONCLUSION}

Both of the pesantren have the same points to improving the religiosity of santri. They are divided into three aspects: increasing the level of hablumminallah (creed, worship, and knowledge) hablumminannas, and hablumminal'alam. These aspects can improve by five learning methods: advice from the Kyai, the study of classical Islamic kitab, Islamic habituation, modeling, reward, and punishment. pesantren of Al-Munawwir Nurussalam and Nurul Ummahat have roles in various ways, namely a) increasing hablumminallah (creed, worship, and knowledge) santri of tahfidz Al-Quran, b) increasing hablumminannas, and c) increasing hablumminal'alam. The methods used to improve the Religiosity of the students of the Al-Quran are a) advice from the Kyai, b) study of classical Islamic books, c) habituation, d) modelling, e) reward, and f) punishment. This study's results can provide significant benefits in the efforts to establish the religious Religiosity for santri in other pesantren in Indonesia and overseas.

\section{REFERENCES}

[1] Sakai, M. (2012). Building a partnership for social service delivery in Indonesia: State and faith-based organisations. Australian Ournal of Social Issues, 47(3), 373 - 388. http://do.org/10.102/j.1839-4655.2012.tb00254.x.

[2] Sakai, M. (2014). Establishing social justice through financial inclusivity: Islamic propagation by Islamic savings and credit cooperatives in Indonesia. TRaNS: Trans-Regional and -National Studies of Southeast Asia, 2(2), 201-222. https://doi.org/10.1017/trn.2014.4

[3] Atabik, A. (2014). the Living Qur'an: Potret Budaya Tahfiz Al-Qur'an di Nusantara. VIII(1), 161-178.

[4] Maksum, M. N. R., Asy’arie, M., \& Aly, A. (2020). Democracy Education Through The Development of Pesantren Culture. Humanities \& Social Sciences
Reviews, $\quad 8(4)$,

https://doi.org/10.18510/hssr.2020.842

$10-17$.

[5] Anam, S., Degeng, I.N.S., Murtadho, N., \& Kuswandi, D. (2019). The Moral Education and Internalization of Humanitarian Values in Pesantren: A Case Study from Indonesia. Journal for the Education of Gifted Young Scientists, 7(4), 815-834. http://dx.doi.org/10.17478/jegys.629726

[6] Isbah, M. F. (2020). Pesantren In The Changing Indonesian Context: History And Current Developments. Qudus International Journal of Islamic Studies (QIJIS), $\quad 8(1)$ https://doi.org/10.21043/qijis.v8i1.5629

[7] Khaidir. E.. \& Suud. F. M. (2020). Islamic Education In Forming Students'characters At As-Shofa Islamic High School. Pekanharu Riau. International .Iournal of Islamic Educational Psychology, 1(1), 50-63.

[8] Wekke, I. (2014). Arabic teaching and learning: A model from Indonesia muslim minority. ProcediaSocial and Behavior Science, 9(1), 69-78. https://doi.org/ 10.1016/j.sbspro.2015.04.236.

[9] Wibowo, A. (2016). Peran pondok pesantren AlHaidar dan pembinaan remaja Desa Penjalin Brangsong Kendal [Undergraduate, UIN Walisongo]. http://eprints.walisongo.ac.id/6040/

[10] Suud. F. M.. \& Madiid. A. (2019). The Studv of Educational Honestv Stages Implementation in an Indonesian School. Humanities \& Social Sciences Reviews, 7(4), 502-510. http://dx.doi.org/10.31838/jcr.07.09.78

[11] Aubusson,P.,Watson,K.,Vozzo, L.,\& Steele, F.(2005).Retrained teachers and school culture: Complex interactions. Teacher Development, 9(1), 59-77. https://doi.org/10.1080/13664530500200241

[12] Baise, M.(2003).Doing democracy in social studies methods. Theory \& Research in Social Education, 31(1), 51-71. https://doi.org/10.1080/00933104.2003.10473215

[13] Hasbullah. (1999, cet ke-3). Sejarah Pendidikan Islam di Indonesia. Jakarta: PT Raja Grafindo Persada.

[14]Dhofier, Z. (2019, cet ke-10). Tradisi Pesantren. Jakarta: LP3ES.

[15] Isbah. M. F. (2020). Pesantren in the Changing Indonesian Context: Historv and Current Develonments. OIIIS (Oudus International Journal of Islamic Studies), 8(1), 65-106.

[16]Putri, F. A. (2012). Perbedaan Tingkat religiusitas dan Sikap terhadap Seks Pranikah antara Pelajar yang bersekolah di SMA Umum dan SMA Berbasis Agama. Calypatra: Jurnal Ilmiah Mahasiswa Universitas Surabaya, 1(1), 1-9.

[17] Asadullah. M. N.. \& Chaudhurv. N. (2010) Religious schools. social values. and economic attitudes: Evidence from Bangladesh. World Development, 38(2), 205-217.

[18] Yusof, S. M., Hameed, A. B., Tahir, R. M., \& Othman, A. (2018, Mei 16). Hablumminallah among Successful Muslim Women Entrepreneur: an Exploratory Study. Jurnal of Academic Research, 1029-1041. doi:10.6007/IJARBSS/v8-i5/4480

[19] Ghufron, M. N., \& Risnawati S, R. (2017, cet ke-2). Teori-Teori Psikologi. (R. Kusumaningratri, Penyunt.) Yogyakarta: Ar-Ruzz Media.

[20]Anwar, M. K., Fahrullah, A., Ridlwan, A. A., Muzaki, M. H., Canggih, C., \& Kautsar, A. (2020). The Influence Of Religiosity On Income And Prosperity: The Indonesian Context. Humanities \& Social Sciences Reviews, 8(2), 213-221. https://doi.org/10.18510/hssr.2020.8225

[21]Shihab, M. Quraish.(2009). Tafsir Al Misbah, Volume 7, Jakarta, Mizan 
[22]El-Menouar, Y., \& Stiftung, B. (2014). the Five Dimensions of Muslim Religiousity. Results of an Empirical Study. 8(1), 53-78. doi:10.12758/mda.2014.003

[23] Bruinessen, M. v. (2015, cet ke-2). Kitab Kuning, Pesantren dan Tarekat. Yogyakarta: Gading.

[24] Khan, Z. H., Watson, P. J., \& Chen, Z. (2016, Juni). Muslim Spirituality, Religious Coping, and Reactions to Terrorism Among Pakistani University Students. J Relig Health, 2086-2098. doi:10.1007/s10943-0160263-2

[25]Zeussa, B. (2016). Problematika Proses Belajar Mengajar Tahfidz Al Qur'an di SD Plus Tahfizul Qur'an Nida Salatiga. Salatiga: IAIN Salatiga.

[26]Huda, K. (2010). Problematika Pembelajaran Tahfidzul Qur'an pada Siswa Kelas V di SDIT Muhammadiyah Al-Kautsar Gumpang Kartasura Tahun Ajaran 2009-2010. Surakarta: Universitas Muhammadiyah Surakarta.

[27] Widigdo, M. S. A. (2020). On Religious Experience: A Critique of John Dewey's Notion of Religious Experience from Muslim Illuminationist Perspective. 16.

[28] Latief, H. (2012). Filantropi Islam dan Aktivisme Sosial Berbasis Pesantren di Pedesaan. Afkaruna: Indonesian Interdisciplinary Journal of Islamic Studies, $\quad 8(2), \quad 167-187$. https://doi.org/10.18196/aiijis.2012.0013.167-187
[29] Sultoni, A., Wasim, A. T., \& Fauzan, A. (2020). Development Of Prophetic Intelligence (Phenomenology Study Of Religious Transformation). International Journal of Islamic Educational Psychology, 1(1), 12-24. https://doi.org/10.18196/ijiep.1102

[30] Song, Y., Lu, S., \& Smiley-Oyen, A. L. (2020). Differential motor learning via reward and punishment. Quarterly Journal of Experimental Psychology, 73(2), 249-259.

[31] Habibi, I., \& Supriatno, T. (2020). Charity Punishment in Islamic Boarding School to Improving Santri Discipline. Nazhruna: Jurnal Pendidikan Islam, 3(3), 342-354.

[32] Ji, J. H., \& Heo, S. E. (2019). The effects of work value and major satisfaction of dental hygiene students on career decision self-efficacy. Journal of Convergence for Information Technology, 9(6), 183193.

[33] Steel, A., Silson, E. H., Stagg, C. J., \& Baker, C. I. (2019). Differential impact of reward and punishment on functional connectivity after skill learning. NeuroImage, 189, 95-105. https://doi.org/10.1016/j.neuroimage.2019.01.009 